\title{
IGF-I enhances cortisol secretion from guinea-pig adrenal gland: In vivo and in vitro study
}

\author{
DIPALI RAHA ${ }^{1}$, SHAMSHUN NEHAR $^{1}$, BHOLA PASWAN ${ }^{1}$, PIERA REBUFFAT $^{2}$, GIULIANO NERI $^{2}$, \\ RANU NASKAR ${ }^{1}$, KIRAN KUMARI ${ }^{1}$, BUSHRA RAZA ${ }^{1}$, N. VENKAT APPA RAO ${ }^{1}$, CARLO MACCHI ${ }^{2}$, \\ NISARGA S. SEN ${ }^{1}$, GASTONE G. NUSSDORFER ${ }^{2}$ and M. FIROZ AHMAD ${ }^{1}$ \\ ${ }^{1}$ Department of Zoology, Ranchi University, Ranchi 834008, India; ${ }^{2}$ Department of \\ Human Anatomy and Physiology, University of Padua, I-35121 Padua, Italy
}

Received February 27, 2007; Accepted March 29, 2007

\begin{abstract}
Insulin-like growth factor (IGF)-I is a ubiquitously synthesized peptide that, along with IGF-II, acts via the IGF-R type I receptor. IGF-I and its receptor are expressed in the adrenal gland of humans and bovines, the secretion of which they seem to stimulate. As in humans and cows, the main glucocorticoid hormone secreted by guinea-pig adrenals is cortisol, and hence we have studied the adrenocortical effects of IGF-I in this species. In vivo experiments showed that prolonged IGF-I administration raised the plasma concentration of cortisol in both normal and dexamethasone/captopriltreated guinea pigs, thereby ruling out the possibility that IGF-I may act by activating the hypothalamic-pituitaryadrenal axis and the renin-angiotensin system. In vitro experiments demonstrated that IGF-I enhanced basal, but not maximally agonist [ACTH and angiotensin-II (Ang-II)]stimulated, cortisol secretion from freshly dispersed guinea-pig inner adrenocortical cells. The IGF-I immuno-neutralization suppressed the IGF-I secretagogue effect, without altering the cortisol response to both ACTH and Ang-II. IGF-I raised cyclic-AMP and inositol triphosphate release from dispersed guinea-pig cells, and the effect was reversed by the adenylate cyclase inhibitor SQ-22536 and the phospholipase-C (PLC) inhibitor U-73122. SQ-22536, U-73122, the protein kinase (PK) A inhibitor H-89 and the PKC inhibitor calphostin-C decreased by approximately $50 \%$ the cortisol response of dispersed cells to IGF-I, and the combined exposure to SQ22536 and U-73122 abolished it. We conclude that IGF-I stimulates glucocorticoid secretion from guinea-pig adrenocortical cells, acting via selective receptors coupled to both
\end{abstract}

Correspondence to: Professor G.G. Nussdorfer, Department of Human Anatomy and Physiology, Section of Anatomy, Via Gabelli 65, I-35121, Padua, Italy

E-mail: gastone.nusdorfer@unipd.it

Key words: Insulin-like growth factor-I, adrenal gland, cortisol secretion, guinea pig the adenylate cyclase/PKA- and PLC/PKC-dependent signaling cascades.

\section{Introduction}

Insulin-like growth factor (IGF)-I, also named somatomedin-C, once was thought to be exclusively produced by liver under the effect of the hypophyseal growth hormone, of which it mediates the growth promoting action (reviewed in refs. 1,2). Subsequent studies clearly demonstrated the ubiquitous synthesis by stromal cells of IGF-I and its possible nature as autocrine-paracrine mediator. IGF-I and the companion IGF-II act via a common receptor, named IGF-R type I, which, like its ligands, is widely distributed in tissues and organs $(2,3)$.

Many lines of evidence indicate that IGF-I and IGF-R type I are expressed in the mammalian adrenals (4-8), where the main adrenal agonists ACTH and angiotensin-II (Ang-II) up-regulate their expression and enhance IGF-I secretion (9-13). Moreover, the interrelationships between adrenal agonists and IGF-I are reciprocal, inasmuch as the latter has been found to up-regulate the expression of ACTH and Ang-II receptors in adrenals (14-17), making it likely that IGF-I may promote adrenal steroid secretion.

In keeping with this contention, several investigations clearly demonstrated that IGF-I raises basal and agoniststimulated glucocorticoid (cortisol) and androgen secretion from cultured human, bovine and sheep adrenocortical cells, an effect coupled with the up-regulation of expression of some enzymes of steroid synthesis, including $17 \alpha$-hydroxylase, $3 \beta-$ hydroxysteroid dehydrogenase and C21-hydroxylase, but not cholesterol side-chain cleaving enzyme and 11ß-hydroxylase (14-25). However, Naseeruddin and Hornsby (26) reported that IGF-I enhances 11ß-hydroxylase mRNA, without altering $17 \alpha$-hydroxylase expression in bovine adrenocortical cells, and Fujii et al (27) described a clear-cut inhibitory effect of IGF-I on glucocorticoid and cyclic-AMP response of dispersed rat adrenocortical cells to ACTH.

Therefore, it seemed worthwhile to investigate the in vivo and in vitro effects of IGF-I on glucocorticoid secretion of the guinea-pig adrenals. Guinea pig was chosen because its main glucocorticoid hormone is cortisol, as in humans, cows and sheep. 




Figure 1. Effect of the prolonged administration of IGF-I on the blood concentration of cortisol in normal and dexamethasone (dx)/captopril (cpt)treated guinea pigs. Bars are means \pm SD $(n=12)$. Open circles indicate the range. ${ }^{*} \mathrm{P}<0.05$ and ${ }^{* *} \mathrm{P}<0.01$.

\section{Materials and methods}

Animals and reagents. Adult male guinea pigs, either bred in our laboratory facilities (in vivo experiments) or purchased from Charles-River (Como, Italy) (in vitro experiments), were kept under a 12/12-h light/dark cycle (illumination onset at 8:00 a.m.) at $23^{\circ} \mathrm{C}$, and maintained on a standard diet and tap water ad libitum. The study protocol was approved by the local Ethics Committees for Animal Studies. The angiotensinconverting enzyme inhibitor captopril (Aceten) was obtained from Worckhardt India (New Delhi, India) and dexamethasone (Dexona) from Cadilla India (New Delhi, India). The signaling cascade antagonists SQ-22536, U-73122, H-89 and calphostinC (28 and refs. therein) were purchased from Biomol Research Laboratories (Milan, Italy). IGF-I, anti-IGF-I antibody (ab), ACTH, angiotensin-II (Ang-II), bovine serum albumin (BSA), phosphate-buffered saline (BSA), 3'-isobutyl-1-methylxantine (IBMX), and all other chemicals and laboratory reagents were provided by Sigma-Aldrich Corporation (St. Louis, $\mathrm{MO})$.

In vivo experiments. Animals were divided into two groups $(\mathrm{n}=24)$. One group was subcutaneously injected for 14 days with dexamethasone $(2.5 \mathrm{mg} / \mathrm{kg})$ and captopril $(2.5 \mathrm{mg} / \mathrm{kg})$. The other group was given daily injections of $0.9 \% \mathrm{NaCl}$. On the 6th day, half the animals in each group received IGF-I $(1 \mathrm{mg} / \mathrm{kg})$. At the end of the treatment, blood samples were collected from the retro-orbital vein (29), and stored at $-20^{\circ} \mathrm{C}$ until cortisol assay.

In vitro experiments. Dispersed guinea-pig zona fasciculatareticularis (inner) adrenocortical cells were obtained as previously described (29). Cells obtained from 6 guinea pigs were pooled to obtain a single cell suspension, and 4 or 6 cell suspensions for each incubation experiment were employed. Aliquots of each cell suspension $\left(10^{4}\right.$ cells in Krebs-Ringer bicarbonate buffer with $0.3 \%$ glucose and $0.2 \%$ BSA) were incubated as follows: i) IGF-I (from $10^{-12}$ to $10^{-6} \mathrm{M}$ ); ii) ACTH

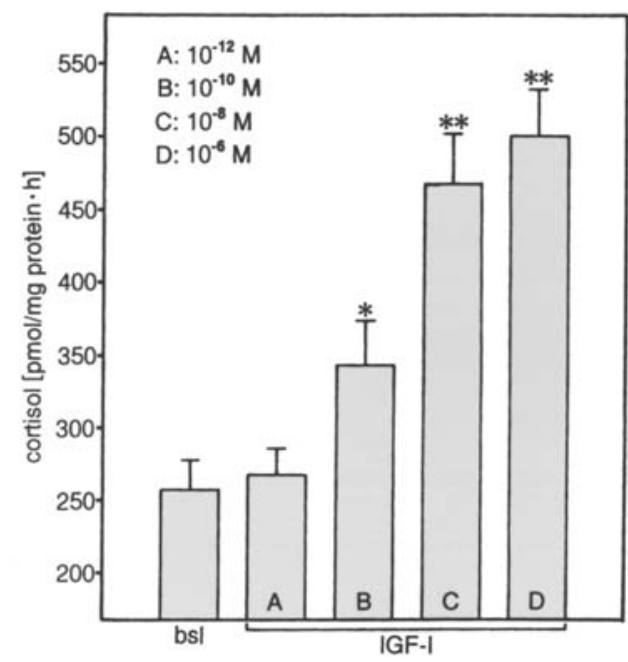

Figure 2. Effect of IGF-I on cortisol secretion from dispersed guinea-pig inner adrenocortical cells. Bars are means \pm SEM $(n=4) .{ }^{*} \mathrm{P}<0.05$ and ${ }^{* *} \mathrm{P}<0.01$ from baseline (bsl) value.

$\left(10^{-9} \mathrm{M}\right)$ or Ang-II $\left(10^{-8} \mathrm{M}\right)$ alone or in the presence of IGF-I $\left(10^{-8} \mathrm{M}\right)$; iii) anti-IGF-I ab $(100 \mathrm{ng} / \mathrm{ml})$ alone or in the presence of IGF-I $\left(10^{-8} \mathrm{M}\right)$, ACTH $\left(10^{-9} \mathrm{M}\right)$ and Ang-II $\left(10^{-8} \mathrm{M}\right)$; iv) SQ-22536 $\left(10^{-8} \mathrm{M}\right)$ alone and in the presence of IGF-I $\left(10^{-8} \mathrm{M}\right)$ or ACTH $\left(10^{-9} \mathrm{M}\right)$ [cyclic-AMP (cAMP) assay]; v) U-73122 $\left(10^{-5} \mathrm{M}\right)$ alone and in the presence of IGF-I $\left(10^{-8} \mathrm{M}\right)$ or Ang-II $\left(10^{-9} \mathrm{M}\right)$ [inositol triphosphate (IP3) assay]; vi) SQ-22536 $\left(10^{-4} \mathrm{M}\right)$, U-73122 $\left(10^{-5} \mathrm{M}\right), \mathrm{H}-89\left(10^{-5} \mathrm{M}\right)$ or calphostin-C $\left(10^{-5} \mathrm{M}\right)$ alone and in the presence of IGF-I $\left(10^{-8} \mathrm{M}\right)$; and vii) SQ-22536 $\left(10^{-4} \mathrm{M}\right)$ plus U-73122 $\left(10^{-5} \mathrm{M}\right)$ alone or in the presence of IGF-I $\left(10^{-8} \mathrm{M}\right)$. The incubation was carried out in a shaking bath at $37^{\circ} \mathrm{C}$ for $60 \mathrm{~min}$ (cortisol secretion) or $10 \mathrm{~min}$ (cAMP and IP3 production), in an atmosphere of $95 \%$ air-5\% $\mathrm{CO}_{2}$. Supernatants were stored at $-80^{\circ} \mathrm{C}$ until assay, and protein concentration of dispersed cells was measured by the BCA protein assay kit (Sigma-Aldrich Corporation).

Cortisol assay. Cortisol blood concentration was measured by enzyme immuno-assay (EIA), as previously detailed (30). Cortisol was extracted from supernatants and purified by high pressure liquid chromatography (HPLC) (31-33), and its concentration was estimated by radio-immunoassay (RIA), using a commercial kit purchased from IRE-Sorin (Vercelli, Italy). Sensitivity, $90 \mathrm{pmol} / \mathrm{l}$; intra- and inter-assay CVs, $6 \%$ and $8 \%$, respectively.

cAMP and IP 3 assays. In the case of cAMP assay, the phosphodiesterase inhibitor IBMX $\left(10^{-4} \mathrm{M}\right)$ was added to prevent cAMP metabolism (28). cAMP and IP3 were extracted from the incubation media (34), and their concentrations were measured by RIA, using the following commercial kits purchased from Amersham Pharmacia Biotech (Little Chalfont, UK). cAMP Biotrak TRK 432 kit: sensitivity, 1 pmol/1; intraand inter-assay CVs 5\% and 7\%, respectively. IP3 Biotrak TRK 1000 kit: sensitivity, 2 pmol/l; intra- and inter-assay CVs, $6 \%$ and $8 \%$, respectively.

Statistics. Data were expressed as means \pm SD or SEM, and their statistical comparison was performed by the paired sample 


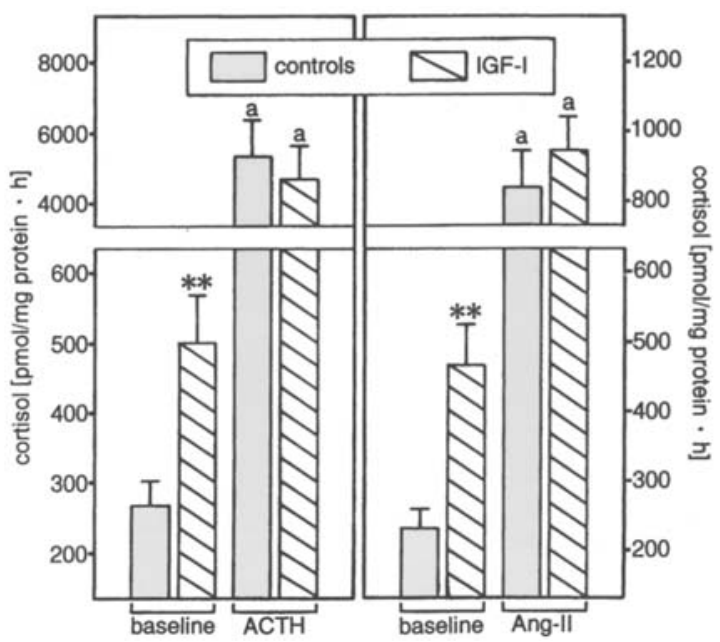

Figure 3. Effects of IGF-I ( $\left.10^{-8} \mathrm{M}\right)$ on basal and agonist-stimulated cortisol secretion from dispersed guinea-pig inner adrenocortical cells. Bars are means \pm SEM $(n=6) .{ }^{* *} \mathrm{P}<0.01$ from the respective control value; ${ }^{\mathrm{P}}<0.01$ from the respective baseline value.

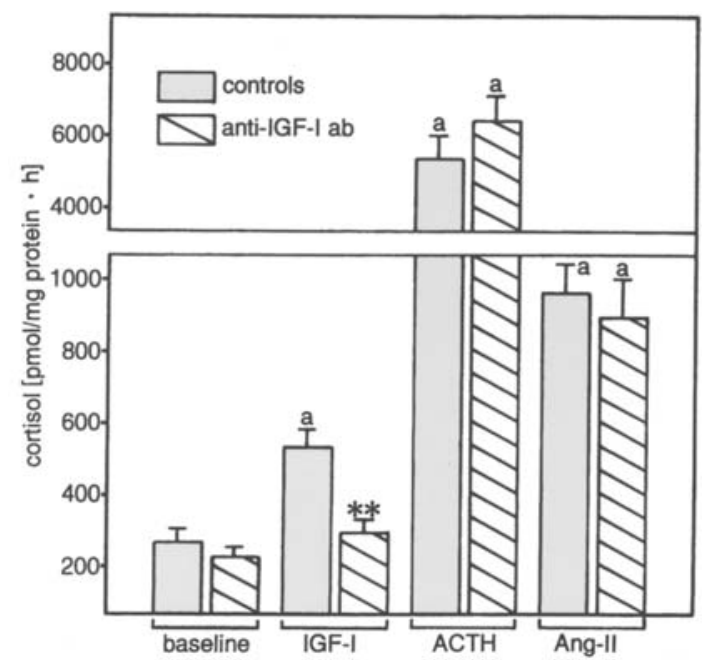

Figure 4. Effects of anti-IGF-I ab $(100 \mathrm{ng} / \mathrm{ml})$ on basal, IGF-I $\left(10^{-8} \mathrm{M}\right)$-, ACTH $\left(10^{-9} \mathrm{M}\right)$ - and Ang-II $\left(10^{-8} \mathrm{M}\right)$-stimulated cortisol secretion from dispersed guinea-pig inner adrenocortical cells. Bars are means \pm SEM $(n=6)$. ${ }^{* *} \mathrm{P}<0.01$ from the respective control value; ${ }^{\mathrm{P}}<0.01$ from the respective baseline value.

t-test (cortisol blood concentration) or by ANOVA, followed by Duncan's multiple range test.

\section{Results}

The prolonged dexamethasone/capropril administration decreased by $47 \%$ the blood concentration of cortisol in guinea pigs. IGF-I treatment for 6 days raised the plasma level of cortisol by $26 \%$ in normal guinea pigs and by approximately 5-fold in dexamethasone/captopril-administered animals. Noteworthy, the cortisol response of the latter group of guinea pigs was approximately two-fold higher than that of normal animals (32 versus $68 \mu \mathrm{g} / \mathrm{ml}$ ) (Fig. 1).

IGF-I concentration-dependently enhanced cortisol secretion from dispersed guinea-pig inner adrenocortical cells, minimal and maximal effective concentrations being

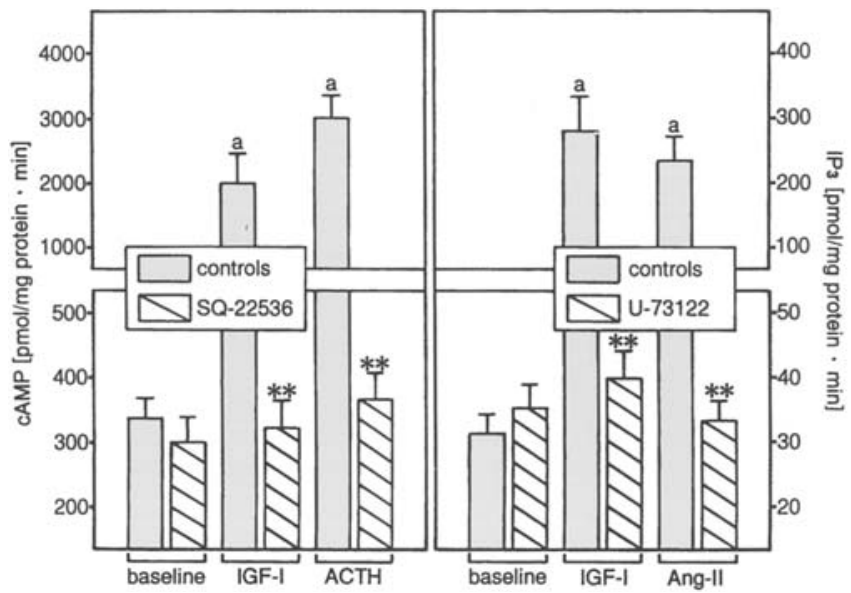

Figure 5. Effects of IGF-I $\left(10^{-8} \mathrm{M}\right)$ on cAMP (left panel) and IP3 release (right panel) from dispersed guinea-pig inner adrenocortical cells. cAMP response to IGF-I and ACTH is suppressed by SQ-22536 $\left(10^{-4} \mathrm{M}\right)$, and IP3 response to IGF-I and Ang-II by U-73122 $\left(10^{-5} \mathrm{M}\right)$. Bars are means \pm SEM $(\mathrm{n}=4) .{ }^{* *} \mathrm{P}<0.01$ from the respective control value; ${ }^{\mathrm{a}} \mathrm{P}<0.01$ from the respective baseline value.



Figure 6. Effects of the signaling cascade inhibitors SQ-22536 $\left(10^{-4} \mathrm{M}\right)$, H-89 $\left(10^{-5} \mathrm{M}\right), \mathrm{U}-73122\left(10^{-5} \mathrm{M}\right)$ and calphostin-C $\left(10^{-5} \mathrm{M}\right)$ on basal and IGF-I ( $\left.10^{-8} \mathrm{M}\right)$-stimulated cortisol secretion from dispersed guinea-pig inner adrenocortical cells. Bars are means $\pm \operatorname{SEM}(n=6)$. ${ }^{*} \mathrm{P}<0.05$ from the respective control value; ${ }^{\mathrm{a}}<0.01$ from the respective baseline value.

$10^{-10}$ and $10^{-8} / 10^{-6} \mathrm{M}$, respectively (Fig. 2). IGF-I $\left(10^{-8} \mathrm{M}\right) \mathrm{did}$ not affect the cortisol response of dispersed cells to either ACTH or Ang-II (Fig. 3). Anti-IGF-I ab suppressed the cortisol response to IGF-I $\left(10^{-8} \mathrm{M}\right)$, without altering either basal or ACTH- and Ang-II-stimulated cortisol secretion (Fig. 4).

Dispersed inner adrenocortical cells displayed marked cAMP and IP3 responses to ACTH and Ang-II, respectively. These responses were abolished by the adenylate cyclase inhibitor SQ-22536 $\left(10^{-4} \mathrm{M}\right)$ and the phospholipase-C (PLC) inhibitor U-73122 $\left(10^{-5} \mathrm{M}\right)$, respectively. IGF-I $\left(10^{-8} \mathrm{M}\right)$ elicited a significant rise in cAMP and IP3 release from dispersed cells, and again the effects were annulled by the two inhibitors (Fig. 5).

The cortisol response of dispersed inner adrenocortical cells to IGF-I $\left(10^{-8} \mathrm{M}\right)$ was significantly lowered (but not 


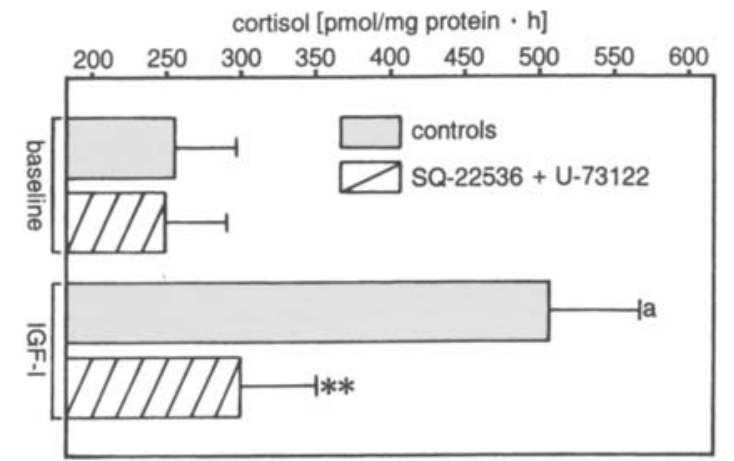

Figure 7. Effects of SQ-22536 $\left(10^{-4} \mathrm{M}\right)$ plus U-73122 $\left(10^{-5} \mathrm{M}\right)$ on basal and IGF-I ( $\left.10^{-8} \mathrm{M}\right)$-stimulated cortisol secretion from dispersed guinea-pig inner adrenocortical cells. Bars are means $\pm \operatorname{SEM}(n=6) .{ }^{* *} \mathrm{P}<0.01$ from the respective control value; ${ }^{\mathrm{a}} \mathrm{P}<0.01$ from the respective baseline value.

abrogated) by SQ-22536 $\left(10^{-4} \mathrm{M}\right)$, the protein kinase (PK) A inhibitor H-89 $\left(10^{-5} \mathrm{M}\right)$, U-73122 $\left(10^{-5} \mathrm{M}\right)$ and the PKC inhibitor calphostin-C $\left(10^{-5} \mathrm{M}\right)$ (Fig. 6). The combined exposure to SQ-22536 and U-73122 completely suppressed the cortisol response to IGF-I (Fig. 7). Basal cortisol secretion was unaffected by the inhibitors (Figs. 6 and 7).

\section{Discussion}

Our present in vivo findings clearly show that IGF-I is able to raise the blood level of cortisol not only in intact guinea pigs, but also in animals where the hypothalamic-pituitary-adrenal axis and renin-angiotensin system had been pharmacologically blocked by dexamethasone and captopril. These observations make it unlikely that the reciprocal interrelationships occurring between IGF-I and ACTH or Ang-II (see Introduction) may underlie the in vivo adrenal secretagogue action of IGF-I, and strongly suggest that this peptide acts directly on guinea-pig adrenocortical cells.

According to this contention, our in vitro experiments provide evidence that IGF-I specifically stimulates secretion of dispersed guinea-pig inner adrenocortical cells, without interfering with the ACTH and Ang-II receptors. In fact, IGF-I raises only basal secretion of cortisol, but not that enhanced by ACTH or Ang-II. Moreover, the immuno-neutralization of IGF-I with a selective $a b$ annuls the secretagogue action of IGF-I, but does not alter the secretory response of dispersed cells to ACTH or Ang-II.

The lack of effect of IGF-I on agonist-stimulated cortisol secretion from guinea-pig adrenocortical cells is at variance with that occurring in human, bovine and sheep adrenocortical cells (14-25). Apart from inter-species differences, it is likely that this discrepancy may ensue from the different experimental approaches. In fact, previous findings were obtained in cultured adrenocortical cells exposed for 24-72 h to IGF-I, while our data enlighten the acute $(60 \mathrm{~min})$ effect of IGF-I. Evidence has been provided that the prolonged exposure to IGF-I upregulates the expression of ACTH and Ang-II receptors in adrenocortical cells (14-17), thereby explaining their increased secretory response to the two agonists.

Our observations may suggest that the acute secretagogue action of IGF-I is mediated by receptors (IGF-R type I ?) that share with ACTH and Ang-II a common signaling mechanism.
This could obviously prevent any additivity between the secretory responses elicited by maximal effective concentrations of IGF-I $\left(10^{-8} \mathrm{M}\right)$ and ACTH $\left(10^{-9} \mathrm{M}\right)$ or Ang-II $\left(10^{-8} \mathrm{M}\right)$. Compelling evidence indicates that the main signaling mechanisms mediating the secretagogue action of ACTH and Ang-II on adrenocortical cells involve the activation of adenylate cyclase and PLC-dependent cascades (35-37 and refs. therein), and our present findings show that the same occurs for the acute secretagogue action of IGF-I.

The following pieces of evidence support this view: i) IGF-I enhances cAMP and IP3 production from dispersed guinea-pig inner adrenocortical cells; ii) the adenylate cyclase inhibitor SQ-22536 and the PLC inhibitor U-73122, at a concentration able to abrogate cAMP response to $\mathrm{ACTH}$ and $\mathrm{IP}_{3}$ response to Ang-II, respectively, suppress cAMP and IP3 responses of guinea-pig adrenocortical cells to IGF-I; iii) SQ-22536 and U-73122, as well as the PKA and PKC inhibitors H-89 and calphostin-C, at concentrations that were previously found to block the PK activation-evoked adrenocortical-cell responses $(32,34,38)$, cause an approximate $50 \%$ inhibition of the IGF-Iinduced cortisol secretion from guinea-pig adrenocortical cells; iv) the simultaneous exposure to SQ-22536 and U-73122 abolished cortisol response to IGF-I; and finally v) no signaling cascade inhibitor per se affects the basal cortisol secretion over 60 min of static incubation, thereby ruling out the possibility that their effect was due to a nonspecific toxic lesion of the steroidogenic machinery of guinea-pig inner adrenocortical cells.

Taken together, our findings allow us to conclude that IGF-I stimulates glucocorticoid secretion from guinea-pig adrenals, probably acting via specific receptors coupled to both the adenylate cyclase/PKA- and PLC/PKC-dependent cascades. Further studies are needed to ascertain the physiological relevance of our in vivo and in vitro findings, in light of the hypothesis that locally synthesized IGF-I may mediate in a paracrine manner some of the adrenal chronic effects of ACTH and Ang-II $(2,16,39)$.

\section{Acknowledgements}

We are indebted to Miss A. Coi for her outstanding secretarial support and help in the search and delivery of bibliographic items.

\section{References}

1. Holly JMP and Wass JAH: Insulin-like growth factors; autocrine, paracrine or endocrine? New perspectives of the somatomedin hypothesis in the light of recent developments. J Endocrinol 122: 611-618, 1989

2. Le Roith D, Bondy C, Yakar S, Liu JL and Butler A: The somatomedin hypothesis: 2001. Endocr Rev 22: 53-74, 2001.

3. Nissley P and Lapaczynski W: Insulin-like growth factor receptors. Grow Factors 5: 29-43, 1999.

4. Pillion DJ, Yang M and Grizzle WE: Distribution of receptors for insulin and insulin-like growth factor I (somatomedin C) in the adrenal gland. Biochem Biophys Res Commun 154: 138-145, 1988.

5. Pillion DJ, Arnold P, Yang M, Stockard CR and Grizzle WE: Receptor for insulin and insulin-like growth factor-I in the human adrenal gland. Biochem Biophys Res Commun 165: 204-211, 1989.

6. Shigematsu K, Niwa M, Kurihara M, Yamashita K, Kawai K and Tsuchiyama I: Receptor autoradiographic localization of insulin-like growth factor-I (IGF-I) binding sites in human fetal and adult adrenal glands. Life Sci 45: 383-389, 1989. 
7. Faiçal S, Maciel RMB, Nosé-Alberti V, Santos MC and Kater CE: Immunodetection of insulin-like growth factor I (IGF-I) in normal and pathological adrenocortical tissue. Endocr Pathol 9: 63-70, 1998.

8. Weber MM, Fottner C and Wolf E: The role of the insulin-like growth factor system in adrenocortical tumorigenesis. Eur J Clin Invest 30 (suppl 3): 69-75, 2000.

9. Louveau I, Penhoat A and Saez JM: Regulation of IGF-I receptors by corticotropin and angiotensin-II in cultured bovine adrenocortical cells. Biochem Biophys Res Commun 163: 32-36, 1989.

10. Penhoat A, Naville D, Jaillard C, Chatelain PG and Saez JM: Hormonal regulation of insulin-like growth factor I secretion by bovine adrenal cells. J Biol Chem 264: 6858-6862, 1989.

11. Penhoat A, Leduque P, Jaillard C, Chatelain PG, Dubois PM and Saez JM: ACTH and angiotensin-II regulation of insulinlike growth factor-I and its binding proteins in cultured bovine adrenal cells. J Mol Endocrinol 7: 223-232, 1991.

12. L'Allemand D, Penhoat A, Blum W and Saez JM: Is there a local IGF-system in human adrenocortical cells? Mol Cell Endocrinol 140: 169-173, 1998.

13. Otsuka F, Ogura T, Yamauchi T, Kataoka H, Kishida M, Miyatake N, Mimura Y, Kageyama J and Makino H: Long-term administration of adrenocorticotropin modulates the expression of IGF-I and TGF-B1 mRNAs in the rat adrenal cortex. Growth Horm IGF Res 9: 41-51, 1999.

14. Penhoat A, Jaillard C and Saez JM: Synergistic effects of corticotropin and insulin-like growth factor-I on corticotropin receptors and corticotropin responsiveness in cultured bovine adrenocortical cells. Biochem Biophys Res Commun 165: 355-359, 1989.

15. L'Allemand D, Penhoat A, Lebrethon MC, Ardèvol R, Baehr V, Oelkers W and Saez JM: Insulin-like growth factors enhance steroidogenic enzyme and corticotropin receptor messenger ribonucleic acid levels and corticotropin steroidogenic responsiveness in cultured human adrenocortical cells. J Clin Endocrinol Metab 81: 3892-3897, 1996.

16. Penhoat A, Chatelain PG, Jaillard C and Saez JM: Characterization of somatomedin-C/insulin-like growth factor-I and insulin receptors on cultured bovine adrenal fasciculata cells. Role of these peptides on adrenal cell function. Endocrinology 122: 2518-2526, 1998

17. Le Roy C, Li JY, Stocco DM, Langlois D and Saez JM: Regulation by adrenocorticotropin (ACTH), angiotensin-II, transforming growth factor- $\beta$, and insulin-like growth factor I of bovine adrenal cell steroidogenic capacity and expression of ACTH receptor, steroidogenic acute regulatory protein, cytochrome P450c17, and 33-hydroxysteroid dehydrogenase. Endocrinology 141: 1559-1607, 2000.

18. Begeot M, Langlois D and Saez JM: Insulin-like growth factor-I and insulin increase the stimulatory guanine nucleotide binding protein (Gs) in cultured bovine adrenal cells. Mol Cell Endocrinol 66: 53-57, 1989.

19. Naaman E, Chatelain PG, Saez JM and Durand P: In vitro effect of insulin and insulin-like growth factor I on cell multiplication and adrenocorticotropin responsiveness of fetal adrenal cells. Biol Reprod 40: 570-577, 1989.

20. Langlois D, Hinsch KD, Saez JM and Begeot M: Stimulatory effect of insulin and insulin-like growth factor I on Gi proteins and angiotensin-II-induced phosphoinositide breakdown in cultured bovine adrenal cells. Endocrinology 126: 1867-1872, 1990.

21. Pham-Huu-Trung MT and Binoux M: Insulin-like growth factor I (IGF-I) induces cortisol production in bovine adrenocortical cells in primary culture. J Steroid Biochem 36: 583-588, 1990.

22. Pham-Huu-Trung MT, Villette JM, Bogyo A, Duclos JM, Fiet J and Binoux M: Effects of insulin-like growth factor I (IGF-I) on enzymatic activity in human adrenocortical cells. Interactions with ACTH. J Steroid Biochem Mol Biol 39: 903-909, 1991.

23. Kristiansen SB, Endoh A, Casson PR, Buster JE and Hornsby PJ: Induction of steroidogenic enzyme genes by insulin and IGF-I in cultured human adrenocortical cells. Steroids 62: 258-265, 1997.

24. Mesiano S, Katz SL, Lee JY and Jaffe RB: Insulin-like growth factors augment steroid production and expression of steroidogenic enzymes in human fetal adrenal cortical cells: implications for adrenal androgen regulation. J Clin Endocrinol Metab 82: 1390-1396, 1997.
25. Fottner C, Engelhardt D and Weber MM: Regulation of steroidogenesis by insulin-like growth factors (IGFs) in adult human adrenocortical cells. IGF-I and, more potently, IGF-II preferentially enhance androgen biosynthesis through interaction with the IGF-I receptor and IGF-binding proteins. J Endocrinol 158: 409-417, 1998

26. Naseeruddin SA and Hornsby PJ: Regulation of $11 \beta-$ and $17 \alpha-$ hydroxylases in cultured bovine adrenocortical cells: 3',5'-cyclic adenosine monophosphate, insulin-like growth factor I, and activators of protein kinase C. Endocrinology 127: 1673-1681, 1990.

27. Fujii H, Iida S, Tsugawa M, Gomi M, Moriwaki K and Tarvi S: Inhibitory effect of somatomedin C/insulin-like growth factor I on adrenocorticotropin- or forskolin-induced steroidogenesis in isolated rat adrenocortical cells. Endocrinology 126: 26-30, 1990.

28. Mazzocchi G, Rebuffat P, Ziolkowska A, Rossi GP, Malendowicz LK and Nussdorfer GG: G protein receptors (GPR) 7 and 8 are expressed in human adrenocortical cells, and their endogenous ligands neuropeptides B and W enhance cortisol secretion by activating adenylate cyclase- and phospholipase Cdependent signaling cascades. J Clin Endocrinol Metab 90: 3466-3471, 2005

29. Raha D, Tortorella C, Neri G, Prasad A, Raza B, Raskar R, Dubey R, Sen NS, Macchi C, Malendowicz LK, Ahmad MF and Nussdorfer GG: Atrial natriuretic peptide enhances cortisol secretion from guinea-pig adrenal gland: evidence for an indirect paracrine mechanism probably involving the local release of medullary catecholamines. Int J Mol Med 17: 633-636, 2006.

30. Appa Rao NV, Sen NS, Sinha PD and Ahmad MF: Effect of Metenkephalin of the cortisol profile of palm squirrel (Funambulus pennanti, Wroughton). Eur Arch Biol 105: 7-11, 1994.

31. Neri G, Andreis PG, Prayer-Galetti T, Rossi GP, Malendowicz LK and Nussdorfer GG: Pituitary adenylate cyclase-activating peptide enhances aldosterone secretion of human adrenal gland: evidence for an indirect mechanism, probably involving the local release of catecholamines. J Clin Endocrinol Metab 81: 169-173, 1996.

32. Andreis PG, Rucinski M, Neri G, Conconi MT, Petrelli L, Panigotto PP, Malendowicz LK and Nussdorfer GG: Neuropeptides $\mathrm{B}$ and $\mathrm{W}$ enhance the growth of human adrenocortical carcinoma-derived NCI-H295 cells by exerting MAPK p42/p44mediated proliferogenic and antiapoptotic effects. Int $\mathrm{J}$ Mol Med 16: 1021-1028, 2005.

33. Spinazzi R, Petrelli L, Guidolin D, Carraro G, Casale V, Tortorella C, Neri G, Albertin G, Andreis PG and Nussdorfer GG: In vitro culture on Matrigel favors the long-term maintenance of rat zona glomerulosa-cell differentiated phenotype. Int J Mol Med 17: 1101-1110, 2006.

34. Andreis PG, Malendowicz LK, Rebuffat P, Spinazzi R, Ziolkowska A and Nussdorfer GG: Galanin enhances corticosterone secretion from dispersed rat adrenocortical cells through the activation of GAL-R1 and GAL-R2 receptors coupled to the adenylate cyclase-dependent signaling cascade. Int J Mol Med 19: 149-155, 2007.

35. Nussdorfer GG, Rossi GP, Malendowicz LK and Mazzocchi G: Autocrine-paracrine endothelin system in the physiology and pathology of steroid secreting tissues. Pharmacol Rev 51: 403-438, 1999.

36. Spät A and Hunyady L: Control of aldosterone secretion: a model for convergence in cellular signaling pathways. Physiol Rev 84: 489-539, 2004.

37. Spinazzi R, Andreis PG and Nussdorfer GG: Neuropeptide-Y and Y-receptors in the autocrine-paracrine regulation of adrenal gland under physiological and pathophysiological conditions (Review). Int J Mol Med 15: 3-13, 2005.

38. Spinazzi R, Ziolkowska A, Neri G, Nowak M, Rebuffat P, Nussdorfer GG, Andreis PG and Malendowicz LK: Orexins modulate the growth of cultured rat adrenocortical cell, acting through type 1 and type 2 receptors coupled to the MAPK p42/p44- and p38-dependent cascades. Int J Mol Med 15: 847-852, 2005.

39. Ho MM and Vinson GP: Peptide growth factors and the adrenal cortex. Microsc Res Tech 36: 558-568, 1997. 